\title{
Making Invisible Cattle: Commodifying Genomic Knowledge in Dairy Cattle Breeding
}

\author{
ANNIKA LONKILA \\ University of Eastern Finland \\ Finnish Environment Institute
}

\begin{abstract}
Molecular genomics have revolutionized the dairy cattle breeding industry in recent years. Genomic technologies, seen as capable for solving challenges ranging from farm viability to animal health and sustainability, have restructured dairy breeding networks and markets globally and transformed relationships between humans, non-human animals, and technologies. Furthermore, they have created possibilities for increased commercialization and appropriation of breeding practices and the intensified objectification and machination of animals. In this paper I combine the theories of market creation and commodification to understand how the 'genomic market' was created in Finnish dairy cattle breeding and examine the repercussions of this development within dairy production more broadly. By drawing on textual and interview data by breeding companies and cattle owners, I explore how genomic knowledge becomes stabilized and objectified as a commodity. I also examine how cattle owners and cattle become requalified as actors within this market and how they co-produce and contest the process in significant ways. My results indicate that the commodification of genomic knowledge contributes to a powerful reinterpretation of Finnish dairy production and can have important moral and material repercussions for human and non-human animal lives within those networks.
\end{abstract}

KEYWORDS: livestock breeding; commodification; genomic technologies; cattle; markets 


\section{Introduction}

In this paper I set out to examine the processes of creating markets for new technologies and commodifying bovine genomic knowledge. I explore this issue by focusing on the emergence of genomic knowledge as a market object in the Finnish dairy cattle breeding market. Although genomic technologies have "revolutionized" most dairy cattle breeding programs in the world over the past few years (Boichard et al. 2015), their use has not generated much public or academic interest. Over the past few years, genomic knowledge has become a highly marketable entity that entangles cattle, cattle owners, and organizations more tightly in international breeding networks and the lucrative markets of global biotechnological development. Generally, studies have shown that biotechnological development in agriculture can lead to the concentration of power and capital (Goodman and Redclift 1991) and increased spatial inequalities (Whatmore 1994). However, the documented variety of responses to (bio) technological development in livestock breeding in the UK (Gibbs et al. 2009) calls for a less deterministic view and further research on the social, economic, and ethical perspectives of "the genomic revolution" in different geographical contexts. ${ }^{1}$ This paper provides a localized perspective on the mechanisms of market creation and genomic commodification in the Finnish breeding networks. The analysis highlights the potential of genomic technologies to transform organizational relationships and practices and work as disruptive agents in markets (Hannachi and Tichit 2016). Furthermore, it focuses on their potential to restructure knowledge practices on farms and have significant, material effects on bovine lives. ${ }^{2}$

Molecular genomics are increasingly deployed to accelerate genetic progress within livestock breeding to create animals that better conform to the needs of modern dairy production. In genomic selection, scientists look for correspondence between deviation in the DNA sequencing patterns and variation in phenotypic traits, such as structure, milk production levels or udder health (Hayes et al. 2013). Genomic technologies

1 The few existing studies include research on "geneticisation" and the transformed geographies of the UK's cattle and sheep industries (Gibbs et al. 2009; Morris and Holloway 2009; 2014; Holloway and Morris 2008; 2012; 2014) and on the ethics of biotechnological enhancement of livestock (Twine 2010).

2 This paper also contributes to further understanding of the repercussions of capitalizing upon non-human animals as "lively commodities" - a process that is being increasingly contested as enabling increased oppression and objectification (Collard and Dempsey 2013; Collard 2014; Joyce et al. 2015, Twine 2010). 
hold enormous promise: not only do they double the speed of breeding ${ }^{3}$, they help to pry open the "black box" of animal bodies and the mystery of heredity (Lewontin 1977) and better expose the regenerative "genetic capital" invested in cattle in a potentially endless circle of accumulation (Ritvo 1995). Building on the earlier success of breeding practices based on quantitative genetics, genomic knowledge practices replace "traditional" breeding practices based on visual evaluations and records of ancestry (Holloway and Morris 2008), although new methods of breeding and ways of knowing cattle are also contested (Holloway and Morris 2012). Wide adoption of genomic technologies requires work in adjusting the farm site to better conform to the genomic market, and this has potential to transform breeding and dairy production more broadly.

The Finnish breeding markets make an intriguing object of study in this respect: the introduction of genomic selection seems to have proceeded very fast and extensively in Finland, although comparative research is still lacking globally. In the next chapter I interweave theories of market creation (e.g. Callon et al. 2002) and commodity creation (Parry 2004; 2008), especially related to commodifying "life itself", to explore how this process has taken place and what may become of it. The empirical focus of this paper is on the Finnish market leader, a breeding co-op, and I use content and discourse analysis inspired by actor network theory to symmetrically examine the role of both human and non-human actors in the process of commodifying genomic knowledge. My primary research questions are: how does genomic knowledge emerge as a market object - and how is the "genomic market" created? Inspired by the theory of market creation, I explore how these processes rest upon building new relations - detachments and attachments - between actors in Finnish breeding networks. In other words, the perspective of market creation connects the discussion on commodifying genomic knowledge to its broader context, draws a wider group of actors into the analysis and exposes the effects of commodification on those actors. Thus, my further research questions focus on how work on genomic commodification can transform the farm space as part of the genomic market. I ask what repercussions this work has for the knowledge practices and both human and non-human actors on the farm, and how they are re-enacted by and contest the new relations on the market.

3 The rate of genetic gain is estimated to double for dairy cattle by decreasing the generation interval and increasing the selection intensity (Hayes et al. 2013). 


\section{Studying the commodification of genomic life}

In recent years, knowledge of the bovine genome has entered into markets as a transferrable and measurable entity that can be bought and sold - in other words, as a commodity. Yet the process of commodification of "life itself" requires extensive and continuous work: research suggests that managing the inescapable, messy materialities of biological entities sets specific obstacles for creating new commodities. The topic has interested scholars extensively in the past decade, especially in relation to human bodies (e.g. Parry 2008), plants (e.g. Kloppenburg 2005), and "genomic life" (see Parry 2004; Sunder Rajan 2006; Thacker 2005). Commodities that successfully circulate in markets need to become stabilized, individuated and abstracted (Castree 2003; Prudham 2007), and the "liveliness" of biological entities can be difficult to tame. Biotechnologies can be used to facilitate this process, as they render living material in decorporalized ways and help to emphasize informational attributes over a more comprehensive, material understanding of life (Parry 2004).

However, commodity creation needs to be examined critically: commodities do not emerge simply by some unknown force, suddenly and unavoidably. Commodities are performed into being through meticulous work by various "lay" and "expert" actors, human and non-human, attempting to agree on what properties attached to entities qualify them as subjects of economic activity (Callon et al. 2002, 198; Parry 2008,1136 ). First of all, "commodity candidacy" is not inherently built into things (Parry 2008, 1136); it is only "a phase in the life of some things" (Dant 1999, 24), something that must be continuously worked upon. In addition, connecting commodity creation to markets helps to make sense of its dependency on the precarious "double movement" of detachment and attachment between the commodity, the market, and its various actors (Callon et al. 2002, 201; Callon and Muniesa 2005).

Detachments and attachments are ties between knowledge practices, actors, and spaces, which can become forged and severed at the same time within markets (Berndt and Boeckler 2009). Detachment refers to the separation of an entity from its environment both discursively and materially, performing a de-contextualization characteristic to commodification (Joyce et al. 2015). In other words, entities become objectified, differentiated from other commodities within a certain market; transformed into a "thing" that holds together (Callon and Muniesa 2005, 1233). Furthermore, detachment helps to understand both the discursive and the material practices often employed in attempting to control the "liveliness" of the genome. Taking both types of practices into account is crucial when attempting to understand the processes of mar- 
ket creation. Discursive practices, including reductions and simplifications, are commonly intended to stabilize the uncertainties inherent to genomics and living bodies (e.g. Rossi 2013). Detachment can also take a material form: tools such as breeding indices characteristically distance breeding from the farm - from both cattle owners and cattle - and place it in laboratories and the realm of scientific knowledge. Furthermore, as genomic technologies become distinguished as marketable services, they have the potential to appropriate more traditional knowledge practices such as aesthetic and physical evaluations of cattle, which can have many varying cultural, economic, and ethical consequences (Holloway and Morris 2008; 2012; Lorimer and Driessen 2013).

However, markets are not successfully created without also forming new attachments that connect the commodity with the relations and values of the customers' world (Callon et al. 2002). In other words, commodity candidacy fails to be established if the potential customers do not become engaged with it, don't understand it, or significantly contest it (Parry 2008). As an example, genomic breeding technologies have been marketed as solutions to specific, perceived issues of the producers' world, such as the decreasing economic viability of dairy farms. In relation to biological entities and complicated scientific knowledge, discursive practices are commonly used as tools for attaching commodities to both the market and the public realm through simplifications and translations (Mol and Law 2002; Wynne 2005). In other words, the complex biology of living things can only emerge as "obvious" - devoid of any genetic "white noise" - through a large number of conceptual apparatus (Franklin and Lock 2003, 98; Ritvo 1995). Thus, the same simplifications, such as breeding indices, that can be used to detach the genome from the living anima for circulation in markets can also help to attach it to the potential customer's world. Yet something of the complexity of the entity is always lost in the process (Mol and Law 2002), which renders any simplifications precarious, always susceptible to contestation. They are continuously put on trial by human and other actors, and not least by the liveliness of the entities themselves. Furthermore, in breeding, humans and cattle become so complexly entangled that any forms of contestation will always be coproduced by them both (Holloway and Morris 2012 , 74). This leads to a dynamic relationship between complexity and simplicity in the various "genomic translations".

Finally, the actors may become transformed as well: new attachments can also be formed by transforming the potential customers' world to better adapt to the new emerging commodity (Callon and Muniesa 2005, 1234). Morris and Holloway (2014, 151) found that in marketing the genetic breeding technologies in the UK, those cattle owners participating in the technologies were enacted as confident, progressive, and 
contributing to the overall profitability of livestock production, while those unwilling to engage with new practices were seen as "problematic obstacles". Cattle owners are also increasingly being called upon to engage with genetic breeding practices in order to create "better" animal bodies (Morris and Holloway 2014, 150) that conform to the concept of "the ideal cow" of the genomic era.

Thus, the view of commodity creation adopted here underlines that genomic knowledge in breeding can be neither understood nor judged in isolation from the relations which bring it into being (Parry 2008, 1143, my emphasis). Commodity candidacy always emerges in a specific context, constituted by the ecological, economic, cultural, and moral relations that entities embody in a particular place and time (Parry 2008; Joyce et al. 2015). ${ }^{4}$ I set out to examine how these relations, detachments and attachments are built - and become contested - in introducing genomic knowledge to Finnish breeding markets. Importantly, this work has potential to significantly transform the farm through attempts to attach genomic knowledge to it. Furthermore, I pay special attention to contestations: the entangled ways in which the human and non-human actors involved resist and transform the process of "commodifying life". In what follows, I situate the process of market and commodity creation in their specific context within Finnish dairy cattle breeding, and explicate my methodological approach and present the empirical material in more detail.

\section{Genomic knowledge on the Finnish breeding markets: the case and its scrutiny}

The Finnish breeding market is characterized by a centralized market structure: one not-for-profit co-operative holds approximately $90 \%$ of the dairy cattle breeding market. Genomic evaluations have been very successful: only a few years after its launch virtually all of the co-op's domestic semen sales came from the so-called "genome bulls". The co-op was the first to offer commercial genomic evaluations for cattle in Finland in 2009. The evaluations were developed together with a Nordic breeding corporation co-owned by Finnish, Danish, and Swedish cattle owner co-operatives. ${ }^{5}$

4 Here, it is crucial to focus on the cattle in whose material bodies the commodity resides and from which it originates. Re-centering non-human bodies and agency is especially necessary in socially accepted and mundane sites of the commodification of life such as livestock production where life is always already a market entity.

5 The relationship between the Finnish co-op and the Nordic company is organized as follows: all semen resale and the sale of breeding services are the responsibility of the co-op, while the company controls the Nordic breeding program, produces semen and manages export sales. For many interviewed actors, the boundaries between the two are often blurred: they are perceived as one 
In many respects the co-op pioneered the "the genomic revolution" in Finland. In my empirical analysis I have followed the material and discursive practices that allowed this rapid commodification of genomic knowledge to occur. There is a particular focus on the detachments and attachments built by the co-op in the process of commodity and market creation, as well as on the associated contestations based on the farm. The collection of empirical material evolved as new questions emerged during the analysis.

I started the analysis by going through the co-op marketing materials and articles written in the co-op magazine, Nauta, from 2000 to $2015 .{ }^{6}$ From this material, I selected 111 texts for an in-depth thematic analysis, which concentrated on the practices of developing the genomic market. Building on content and discourse analysis inspired by actor-network theory (Nimmo 2011; Prior 2008), I asked not only what the documents say, but also how they participate in enacting the commodity within relational networks (Prior 2008). The texts are not seen merely as "flat" representations of reality, but as its enactments, as technologies of translation, performing other ontologies into being and making others invisible (Nimmo 2011, 114). Reading the texts I paid special attention to those enactments that the texts might aim to counter or conceal and specifically to the voices of contestation emerging from both human and non-human actors that might be subdued in the texts. Similarly, while examining the specific phrases and metaphors used in relation to genomic technologies I aimed to remain sesitized to the agency of the non-human, specifically to the "resistant" capabilities of cattle.

With the help of the analyzing software QSR Nvivo 10 I categorized the texts into themes relating to my research questions. First, I included all the editorial articles of the magazine from 2000-2014 (74 articles) to understand how the co-op perceives and enacts the economic, political, and cultural context in which it operates. Three themes emerged from this analysis: first, the overall structural change within Finnish dairy production (the decreasing number of farms and the increasing size of herds ${ }^{7}$ ); second, market risks (the struggle of farms for viability; the pressure to become more competitive; the commercialization of Finnish breeding networks and the opening of

entity especially by cattle owners but also by interviewed officials. Similarly, for the purposes of this article it does not make sense to analyze them separately: instead I perceive them as parts of the same organization.

6 According to the co-op, the Nauta magazine's readership includes about $60-70 \%$ of Finnish dairy farms.

7 There are ca. 8000 farms in Finland; 2000 farms closed down in 2010-2014 (Luke 2015). The average herd size is only 34 cows in Finland (MTK 2015), compared to 156 in Denmark (ICAR 2014) and 54 in the EU-15 (European Commission - EU FADN 2014). 
markets; the pressure to increase efficiency within all aspects of dairy production ${ }^{8}$ ); and third, changing breeding methods (the spread of "data-based" breeding; the launch of the total merit index"; the increased use of genomic technologies). The co-op's categorization of the relevant actors in Finnish breeding markets (researchers, co-op and company officials, cattle owners, and cattle) was also important for the contextualization. These themes frame the co-op's work in developing the genomic commodity and attaching its customers to the genomic market.

Understanding how the co-op contextualizes its work was crucial for further analysis. However, it became clear that the editorial articles alone did not adequately explain how genomic knowledge was transformed into a market object: commodity creation and customer engagement seemed to be taking place elsewhere. Thus, I included the co-op's online marketing materials, as well as a further 37 articles from the Nauta magazine between 2009 and 2015 dealing specifically with genomic selection to the data. I also conducted three expert interviews with the co-op and Nordic company officials that focused on the co-op's practices in building the genomic market (marketing and other forms of customer engagement). With these articles and transcribed interviews I focused on the descriptions of both discursive and material practices that were used in commodifying genomic knowledge. Firstly, I collected every reference to genomic selection from all the material collected so far and found differing discursive framings that I could categorize by the involved actors. Secondly, I categorized descriptions of material practices (e.g. breeding indices) that facilitated the marketing, customer attachment, and objectification of genomic knowledge. Here, I focused on the following research questions: how do cattle owners and cattle become engaged with genomic knowledge practices, and re-enacted as part of the genomic market? Paying special attention to the subdued "traces of relations" (Nimmo 2011, 114) between farmers and the co-op in the texts, I could identify various contestations to which the co-op seemed to be responding. These were especially related to "unruly" cattle owners. The genomic cow at first glance emerged as "under control", but a closer reading focusing on animal agency revealed spaces of contestation.

8 The market opened for competitors after it was ruled that the co-op had abused its dominant market position (FCCA 2014).

9 Breeding indices were developed in the era of quantitative genetics and have been used in commercial dairy breeding for decades. The index value is a statistically processed estimation of the animal's genetic value, based on scores derived from productive, physical and other scores from the animal and its relatives (Holloway and Morris 2008, 1712). 
In my analysis of contestations I aimed to remain sensitized to a symmetrical view of agency without distinctions between the human and non-human (Latour 1993, 94; Nimmo 2011, 113). I also interviewed an additional six co-op board members. I first saw the board members as having a similar role to the co-op officials, as experts on the co-op's practices. Board members, however, are all also owners of commercial dairy herds, so they could provide me with accounts of breeding practices on farms and cattle owners' perspectives. Here, my main interest was to understand how cattle owners, who were closely involved in the co-op's breeding strategy due to their positions of trust, were breeding their cattle in practice. I also wanted to know how they engaged with genomic knowledge in their breeding practices and how they responded to and shaped the co-op's work, both in contextualizing and market building. I themed the transcribed interviews with QSR Nvivo 10 with a focus on these interests. Finally, I conducted one interview with a competing company official. ${ }^{10}$ This discussion helped to outline the spaces of contestation within Finnish dairy breeding in relation to the co-op's work and to genomic knowledge more generally, as well as to the "data-based" breeding practices distanced from farm sites. Below I first examine the processes of detachment and attachment in the genomic market and then go on to explore contestations and attempts to control them, focusing first on the cattle owner and then on cattle.

\section{Commodifying genomic knowledge}

\subsection{Detaching and attaching genomic knowledge}

[...] knowing those genes that directly impact characteristics is factual information about the heredity. (Nauta 2004/1)

The genome of an animal consists of genes that create the frame for the animal's appearance and characteristics. According to genes instructions, the organism interprets and processes actions and [proteins]. The genome can also be called the 'code of life'. (Nauta 2008/1)

[...] until the day comes that we can decide which genes we pick and choose from parents to be transferred to the offspring. (Nauta 2011/5)

10 Both of the competitors were contacted but only one consented to the interview at the time. 
In the Nauta magazine, genes are represented by the co-op officials as stable informational objects that have the ability to reveal the absolute truth. As the quotes show, they are attributed with ontological superiority and represented as detachable from their environment and the influence of other genes. In other words, genes are "metaphorically stabilized" (Rossi 2013, 1132) in a manner that is common to the processes of commodification and popularization of genetic knowledge (McAfee 2003; Heller and Escobar 2003; Wainwright and Mercer 2011). Here, the genetic make-up of an organism is represented as extractable from bodies both materially and conceptually, rendered effortlessly transmissible - both to its offspring and across markets as "genetic capital". However, viewing genes as information at all, let alone as the all-revealing "code of life", contradicts most geneticists' view of genes as unruly, embodied and relational objects, attaining meaning only through interactions with other genes, organisms, and environments (Rossi 2014). Such a powerful simplification fails to account for the complexity of genetics, breeding evaluations, and life itself.

In the years preceding its implementation, genomic selection was promoted through a reductionist representation of genes, which also seeps into later representations of genomic selection. This is the case especially in interviews and texts written by non-geneticists such as co-op officials or cattle owners. Even when it is acknowledged that the location of individual genes has not been extensively determined and that genomic selection focuses on gene areas rather than individual genes (Eggen 2012), the genome is portrayed as consisting of the building blocks of life that are capable of conveying precise knowledge about heredity. The fact that access to them is limited is seen as a technological hurdle to be overcome - their status as informational objects is rarely questioned. In other words, the lack of control of the genome is merely being postponed (Wynne 2005, 71) through discursive methods. Building upon this discourse, genomic selection is portrayed in the Nauta magazine as a reliable, fast, efficient, and revolutionary method of accessing the genetic value of animals. Yet, as the next quote shows, in the case of genomic knowledge simplifications always become entangled with the complexity inherent to molecular genomics.

SNP ${ }^{11}$ genotyping makes it possible to recognize the genes that impact characteristics. If we saw that all the animals carrying those genes had the same SNP marker, we could use this knowledge in breeding. But genomic selection is not that simple because we only know a small part of the location of the genes that impact different characteristics. (Nauta 2009/1)

11 Single nucleotide polymorpishm. 
Genomic knowledge was also framed as uncertain in the Nauta magazine. This was the case especially where authority to speak on genomic selection was given to livestock geneticists. In these texts the complexities of genomics were also foregrounded. They highlighted the many benefits of the technology but also its uncertainties, such as lower evaluation certainties - around $60 \%$ compared to over $90 \%$ with progeny data (Pryce and Daetwyler 2012) - or the unknown importance of the combined effects of various genes. ${ }^{12}$ Importantly, however, these uncertainties - the lack of control over the technology and cattle - are portrayed as only temporary or limited in their effect; their continuing relevance is further diminished by suggestions for new practices ${ }^{13}$ and a trust in technological development that will make current uncertainties disappear. Notably, the emphasis was still on the benefits of genomic selection for cattle breeding and the instrumental role of the technology in improving efficiency.

Through this discourse, the co-op aims to "hold together" the complexities inherent to genomic knowledge. To fully achieve this, the new breeding method is attached to existing evaluation criteria that were already familiar to cattle owners. The result is a "genomically evaluated breeding index": the total merit index, which combines genomic knowledge with other types of data. The index works as a "socially necessary abstraction" (Collard and Dempsey 2013, 2690; Robertson 2000, 386) that allows genomic knowledge to circulate freely in markets and be attached to material entities, making them calculable and comparable. Linked to the index number, the genomic commodity can move between the worlds of scientific knowledge and farms. As indices based on quantitative genetics have been a part of dairy cattle breeding for years (Holloway and Morris 2008) before genomic selection, the (genomic) total merit index works as a material practice that attaches genomic knowledge to the cattle owners' world. In the practical realities of breeding, genomic knowledge is only showcased to cattle owners through this apparatus. This attachment is further strengthened by another practice called the "use list", on which the co-op collects its suggestions for inseminations - bulls with the best index values. Many cattle owners routinely use the bulls that appear on this list. ${ }^{14}$

12 Derry $(2015,191)$ has pointed out that around $80 \%$ of the genome has been ignored in genomic evaluations as "junk DNA" that does not seem to transfer traits in any way that we understand.

13 E.g., cattle owners are encouraged to use 5-8 "genome bulls" where they would previously have used one progeny tested bull to battle the risk of lower evaluation certainties (Nauta 2011/3).

14 One interviewed board member suggested that cattle owners with only an "average interest in breeding" perhaps do not even realize that they are purchasing genome-selected semen - they simply use what appears on the "use list" as they always have. 
When you use [the total merit index] [...], you obtain positive progress for all traits of economic importance in the dairy cattle industry. You obtain the highest progress from the 'most expensive traits' such as fat and protein yield and health traits. [...] [The total merit index] is optimized to produce long-living and high-producing cows. (Nordic company official)

The total merit index calculates together 14 separate indexes corresponding with traits such as milk production, udder health, structure, or durability (age at slaughter). Each of these traits has a specific weighting factor based on its economic benefit for the dairy cattle industry. Each animal has a number with a plus or minus sign, with the best bulls currently achieving values in the +40 s. "High index" animals represent the "ideal cow" of the genomic age; animals with lower scores are less valuable. The co-op markets the index with the slogan "the total merit index is all you need", detaching the index from other evaluation criteria available to farmers. The index produces a specific type of dairy cow: the emphasis is strongly on milk production. According to the co-op, the index produces animals that are enduring and easy to manage. The index also places emphasis on health and fertility: genomic knowledge has made it possible to breed for these traits with low heritability. The co-op advertises that through the index, cattle owners can produce "invisible cows".

The animals in the herd with the best breeding values are often invisible. You do not pay special attention to manageable, durable and economically viable animals - they do not demand it. (Nauta 2012/3)

A herd of high index cows becomes so healthy, productive, and tame that individual animals become almost invisible. Invisibility signifies ease, long life, and low costs; benefitting both cattle owners and cattle. The genomic index emerges as a solution to the perceived issues of cattle owners, superior to other breeding methods that fail to provide cows that are suitable to their current demands. According to the co-op, the modern cattle owner has a large herd in a modern cowshed (probably with robot-milking) and has no time to spare for recalcitrant or cumbersome cattle. Importantly, these detachments and attachments create strong assumptions about the desirable qualities of a cow as well as the worlds, identities and goals of the breeders.

The market has completely changed. [...] The ugly truth is that the old thinking, focused on cow families, photographs, animals' frame, or pheno- 
type, has disappeared. Today the selection is based more on numbers and facts than ever before. (Co-op board member)

According to the quote above, there is no room for alternative breeding practices in the genomic era. Yet, it is precisely the simplicity of the total merit index that has been the source of much further complexity. The co-op's suggestion that there is no longer a need, for "obsolete" breeding practices, such as progeny evaluated bulls, has provoked a counter-reaction. The majority of the breeding world may have moved on to "better, faster, and more economical" methods, but there exist those who contest the new methods, and those who benefit from this emerging niche market. In the next two chapters I examine how actors - both cattle owners and cattle - contest genomic breeding practices and how the co-op attempts to hold together the genomic commodity and re-engage unruly actors.

\subsection{Controlling contestation}

The interviews with cattle owners quickly revealed the complexities inherent to the process of creating new market entities: the attachments built by the co-op became easily and often contested in practices. Rather than any declared disagreement with the co-op's strategy, it was the described practices that often revealed an engagement with alternative knowledge practices. Contestations on farms fell into three main categories: contesting genomic selection and the total merit index, contesting "efficiency" as the main goal in breeding, and contesting "the invisible cow". Overall, interviewed cattle owners contest genomic breeding practices because they think "something more" is required to successfully breed animals. This added component usually stems from more traditional, farm-based knowledge practices where looking at the animal or its family line is more important. Some farmers question whether cows can be bred only "by numbers" or "on paper", distanced from the animals themselves. What is common to contesting perspectives is that the total merit index is seen as too simplified and reductive. As the quote below shows, competing companies are attempting to build new markets around this contestation.

[Things go wrong] when breeding is done only on the computer, and you say that "we have calculated economically that all Finnish cattle owners must practice breeding with this average model because this is the road to happiness", and start to lecture the cattle owner from a too theoretical basis, saying "I know what is good for you, you shut up because you do not 
understand." (Competing company official)

Visual evaluations of cattle and breeding practices based on family lines and productive statistics have been a part of breeding for centuries (Holloway and Morris 2008; 2012). Yet genomic knowledge, as a breeding "revolution", has the potential to displace these practices. The co-op's marketing slogan, the total merit index is all you need, has become a specific source of contestation in this regard. Attempting to represent and value a cow solely with one number detaches breeding too far from other established knowledge practices and individual farm realities. Interviewed board members emphasize the need to adjust breeding goals to each herd and farm, and argue that "one size fits all" breeding methods rarely fit anyone well. Furthermore, the co-op advertises that "troubles in the family can be forgotten if [the animal] receives a good genomic index value" (Nauta 2014/2). This means that the genomic score trumps even any bad characteristics that the animal's parents may have had - something that traditionally plays an important part in selection. It seems that it is the strict distinction between genetic and other valuing practices that is the source of much contestation. The suggestion that the genomic index number can stand alone as a criterion that defines a valuable animal sets it apart from previous methods. The cattle owners who contest genomic breeding practices talk of belief and trust: they would have to take a leap of faith and disregard their own expertise to believe in something they cannot see. This indicates that the index has become too far detached from the animal and the lived experience of the farm. The co-op also acknowledges that cattle with the highest index values are "hard to see": they can be neither the most aesthetically pleasing nor the most productive animals.

[Q: Is there resistance towards the [index] and if so, why?]

Yes, because most of [the cattle owners] don't comprehend what it means. [The index] really doesn't point to the cow with the highest milk yield or to your most beautiful cow, but to your most productive cow financially, overall. And that is of course much harder to see. (Co-op board member)

The quote above shows that the discrepancy between different valuation practices is difficult to manage. The index number is the only justification for the valuable genome of an animal - it exists even when it is not visible through more traditional criteria. In other words, the process of valuing life has become "black-boxed" to cattle owners and this easily leads to contestation. As indicated by the farmer in the quote below, if the established evaluation criteria and knowledge practices of the farm do not correlate 
with genomic knowledge, cattle owners can lose trust in the technology as it becomes too detached from their reality. However, partial attachments are more common: cattle owners entangle genomic knowledge with other knowledge practices that for them emphasize its reliability. For example, the cattle owner can only trust the index number with some animals and not others, based on a variety of individual criteria.

In my opinion this genome business hasn't really been that beneficial for our farm so far. [...] In practice you don't really, in my view, see that those animals [with high genome values] would stand out really, or be as excellent as those genomes say. [...] I am not satisfied with it, there are too many discrepancies. [...] I am a little annoyed with this genome craze. (Co-op board member)

The co-op's struggle to fully attach the genomic commodity to farm realities and more traditional breeding practices has given its main competitor a market opportunity. The competitor argues that it is not possible to breed animals without taking into account the actors and material practices not reducible to statistical analysis or, even less, to financial gain; it aims to distinguish its (genomic and other) products by "listening to the cattle owners". At the same time, the co-op is attempting to confront these sites of contestation. It has invested great effort into translating its strategy to cattle owners; to attach the genomic index to their realities. In this work, the co-op has focused specifically on the added economic benefit of breeding with the index. As one official put it, the co-op must convince the cattle owners "to move from the milking stool to the calculator". As the quote below shows, this task cannot be left to geneticists and statisticians alone - the gap between different knowledge practices is too large. The co-op must work as a translator.

[Q: You had a campaign like "one index point equals so-and-so many euros".]

Yes, and that seems to simplify nothing. It seems really hard for [cattle owners] to understand that one too. [...] It was a couple years ago, when I really realized this, when one lady called me, probably from somewhere in upper Savonia and she said "we have this robot business going on here [in the cowshed], and I have been looking at this use list. So how should I pick these bulls when I would like the milk to come quickly with the robot? [...] I was thinking that really, we have people with robots in their cowsheds, and still these basic concepts of ours are not clear. So there is still a lot of work in that, in communication. [...] People who really get these indices and work with them, these "index wizards", they don't even realize that they are 
talking about things that go right over the head for most people. It is mathematics, and in the end, people have very little interest in mathematics. (Co-op board member)

The Danish run their milk farms like businesses. Here [in Finland], that culture is not yet as strong. Of course most farmers are interested in where the money comes from and where it goes to, but we really have a lot of such dabblers who don't... well, who have some forest plots out there that they sell when they need to buy something. [The company's] goal is to show that selective breeding is a tool for making economic choices. (Nordic company official)

The co-op reacts to various contestations that take place in the market. These include the cattle owners' inability to comprehend the new methods, their insistence on sticking to more traditional breeding tools, and an unnecessary focus on non-economic issues. This reveals that there still exists a discrepancy between the realities of Finnish cattle owners and the co-op's "ideal customer". Many dairy farms are still small and family-owned. They are situated in remote rural areas and the cattle owner still personally takes care of her animals. In contrast, the ideal cattle owner of the genomic era seems to be closer to a financially savvy entrepreneur managing a large herd: she understands the correlation between investments in breeding and long-term farm viability and sees (bio)technological development as the solution to potential challenges. Furthermore, the co-op increasingly encourages cattle owners to externalize the task of breeding by purchasing a multitude of breeding services from the co-op. These efforts in productivization and appropriation of more traditional practices seem to be directed at modern cattle owner entrepreneurs with increasingly large herds working in an increasingly competitive market. As the quote above show, the co-op sees Danish farmers as more ideally suited to the genomic market.

[Genomic selection] came with force and it was rushed, and certainly real understanding of what it is, what it is about... and about the reliability of evaluations... well, cattle owners don't understand it. And there is a lot that we don't know. But somehow the cattle owners realized that it is just... faster, faster, faster, and better bulls. They have to change their thinking. (Coop official)

In order to survive in the genomic era, the Finnish cattle owner must transform herself. This is one possible strategy of attaching a commodity into the customer's world: by changing that world (Callon and Muniesa 2005, 1234). These changes are related to 
practical matters, such as modifying the way bulls are used within a herd because of lower evaluation certainties, but also to the outlook on breeding more generally. As the quote above shows, the co-op acknowledges that uncertainty is a part of molecular genomics, but by taking a slightly bigger risk now, cattle owners have a chance to increase their profit. After all, the economic situation is dire: many farms are struggling to stay in business. The total merit index works as a technological fix to this issue: by producing the most "economic" cow it provides a partial solution to the issues of decreasing farm viability. Interviewed officials emphasize that there is no longer room for "dabblers" or "sentimentalists" - nor time to wait for absolute levels of reliability in evaluations. The assumption is that those interested in improving their cows economically and as fast as possible are the future of cattle production and contestations will eventually fade away. In the next chapter I examine how detachments and attachments in the genomic market relate to and are contested by cattle.

\subsection{Making invisible cattle}

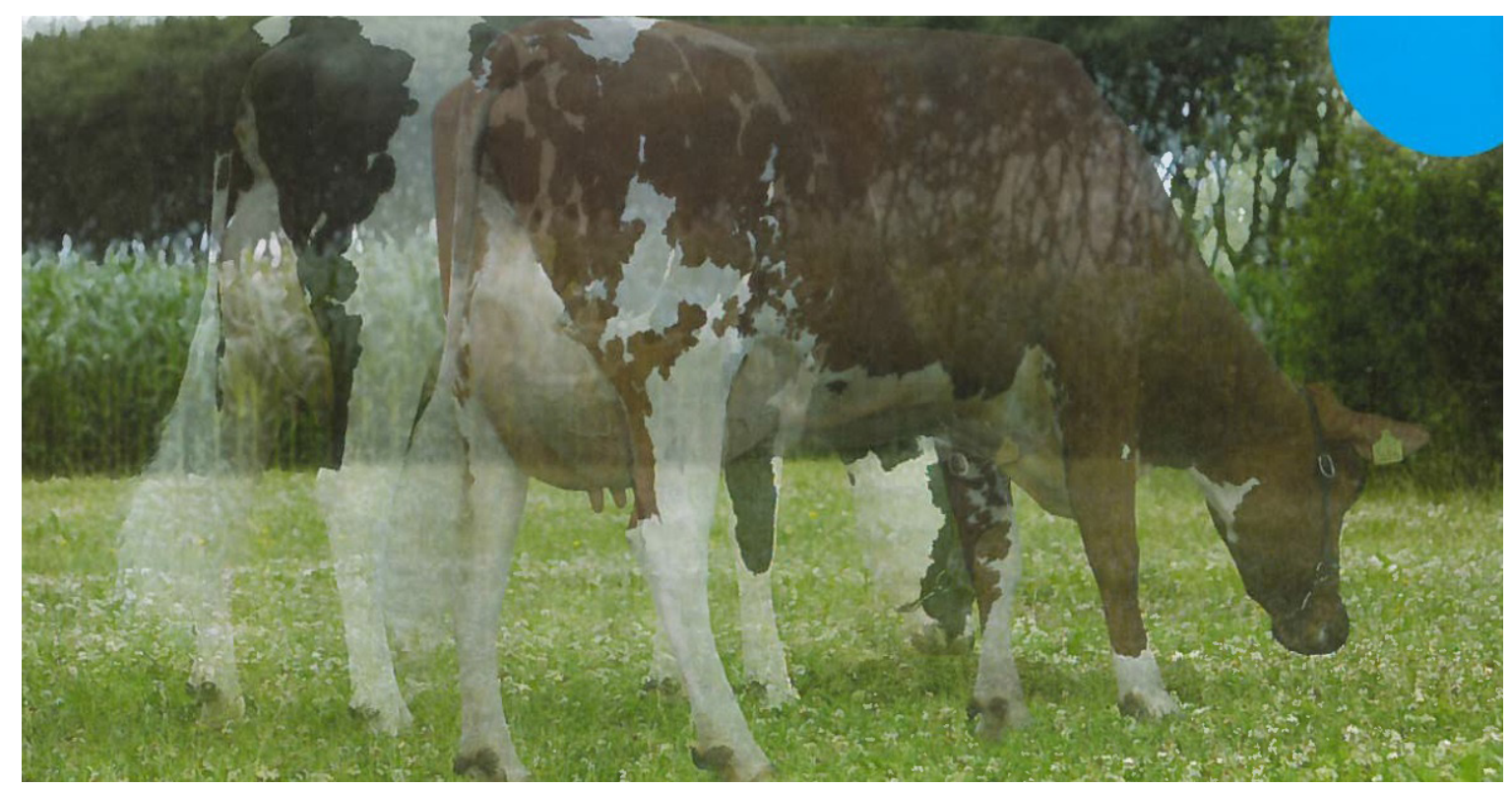

Picture 1. Detail from an advertisement for “invisible cattle" (VikingGenetics). Nauta 2011/4, p. 4.

Genomic knowledge is attached to a representation of the idea dairy cow as invisible; effective, healthy, and easy to handle. For the most part, the co-op portrays cattle as relatively untroubled sites of genomic commodification. The quest to establish control over cattle bodies is revealed in the campaign run by the co-op since 2011 , which 
introduced the slogan "We make cattle invisible". These ideal cows appear in the coop's advertisements as see-through (shown in Picture 1). Invisibility as a breeding goal is closely linked to the genomic breeding index, aiming to provide as comprehensive control over cattle as possible. It is exactly the animals with the best index values that can achieve invisibility in relation to the farmer. Invisibility is seen to benefit both cattle and cattle owners: cattle are healthier and tamer and require less work. Invisible animals, produced by genomic breeding practices, are an important part of the co-op's work in attaching genomic knowledge to cattle owners. They perfectly suit the co-op's understanding of a modern dairy entrepreneur, and indeed invisibility has not become contested by the cattle owners (as shown in the quote below), but rather by cattle themselves.

It's the invisible animals that I want. Cows that you do not notice, they just go there and milk and calve and milk again and nobody even notices they exist. (Co-op board member)

In reinterpreting cattle as invisible, the co-op qualifies animals as the genomic knowledge invested in them. This is manifested in deterministic discourses, such as in a marketing campaign from 2015 that presents an extremely streamlined version of breeding: "[Our] advisors find out the starting point and you give us the goal. The rest is biology" (Nauta 2015/2). Here, animals are reduced to their genetic essence, reflecting a Cartesian understanding of animals as mere materia, as wholly manageable and controllable "beast-machines" (Birke 1994, 117). However, such a powerful simplification fails to account for the complexity of molecular genomics, breeding evaluations, and life itself. It qualifies cattle as "gene stocks", protecting the capital invested in their bodies. Indeed, a closer reading reveals spaces of contestation on the farm, co-produced by both cattle and cattle owners.

By constantly breaking the illusion of invisibility, cattle reveal themselves as troublesome sites for commodification. It is precisely their unstable, uncontrollable materiality - and more specifically the value-generating power of their reproductive process - that is commodified in dairy production. And biological processes are not easily appropriated: fertility is fickle, its functions easily rendered out of order. For example, infertility issues have emerged as unintended consequences of breeding for increased milk production (Nauta 2013/4), underlining how the complexities of cattle genomes can disrupt value chains and resist reduction to index value. Furthermore, certain genomic bulls bred by the Nordic company recently came under scrutiny when their 
genomic evaluations did not hold up: index numbers fell significantly after progeny data came through and genetic progress was not as fast as estimated (Bierma 2015). This shows that nonconforming cattle bodies can contest in material ways the attachments created by the co-op, which in turn can lead to contestations by cattle owners. As indicated earlier, the co-op attempts to manage these contestations by influencing cattle owners' practices in various ways. Importantly, this can have consequences for the lives of cattle as well as human-animal relationships on farms. It is no coincidence that the move from the "milking stool to the calculator" distances the cattle owner further from the animal.

People still want to concentrate a lot on individuals, when we have tried to get rid of them. [...] But there still exist this thinking that individuals are important, and that leads to the cattle owner looking at the cow. (Co-op board member)

Importantly, the goal of invisibility changes the way individual animals are seen in breeding: invisible animals always belong to a herd and individual animals can fade out of focus. The quote above depicts the co-op's broader view: cattle owners would fare better looking at the herd - and the information gathered through the technologies capable of revealing its true value - than at the animals themselves. In the co-op's blog, cattle owners are advised to "trust the numbers" instead of "looking at the cow". This represents a distanced and managerial view of cattle rearing and can restructure the human-animal relationships on farms as the focus shifts individuals towards herd management. Masses make economic sense: hiding individual animal lives renders cattle more "killable" (Buller 2013) and there is less space for human-animal interaction. Technological development in other areas, such as robot milking, supports this trend (Holloway et al. 2014). However, cattle again resist their reduction to a herd of invisible animals. The interviews revealed a complex landscape of human-cattle relationships, constituted simultaneously by care, respect, friendship, and even love for animals. It seems that the messy and material aliveness of cattle makes fruitless any attempts to render cows invisible. Still, human-animal relationships on farms need not be romanticized - in the end they always include death and exploitation for cattle. Accordingly, the interviewed cattle owners were quick to condemn as foolish "dabblers" those that were seen as "losing sight of the essence of cattle ownership" - running a successful business. In livestock farming, human-animal relationships are strictly bordered and representation of cattle as invisible works to secure those boundaries. 


\section{Discussion}

In this paper I set out to examine how genomic knowledge emerged as a market object in the context of Finnish dairy breeding, and how the Finnish dairy farm was reinterpreted in this process. I began by exploring the discursive practices of the co-op as it mediates genomic knowledge to farmers in order to engage them in the genomic market. Following previous research (Wynne 2005, 71), this case shows that when complicated scientific knowledge is popularized, it becomes simplified and its uncertainties are made manageable. I argue that the co-op adopts the role of a "knowledge broker" (Meyer 2010), situated between "scientific" and "vernacular" discourses and knowledge practices. A sort of double translation takes place: the co-op produces its own interpretation of genomic knowledge as a new commodity, necessarily influenced by its motivation of creating a product and engaging cattle owners in new markets. Notably, this representation needs to become attached to the realities of farms. Here, the co-op balances in a precarious "double movement" characteristic to market creation (Callon et al. 2002, 201). On the one hand, the co-op wants to distinguish genomic knowledge practices from other products in the market, but on the other, successful markets are created by building on and renewing existing knowledge practices (Callon et al. 2002). I argue that this network of detachments and attachments is orchestrated by the total merit index. By being attached to the index, genomic knowledge is represented to farmers in a familiar, yet improved, form. Furthermore, the (genomic) index conveys certain representations of Finnish dairy production, which further contribute to the development of a cohesive "genomic market".

Within this reinterpretation of the farm space, the genomic index is portrayed as a tool for the evolved Finnish dairy farm: a viable, modern business with entrepreneurial cattle owners and an increasing herd size, and capable of discarding outdated practices such as focusing on experiential knowledge or individual animals. The farm site is imagined as a space where everything, including the cow, is made calculable and measurable. As the liveliness of cattle, and their genomes, easily renders the commodity unstable and creates spaces of contestation, it follows that the "genomic cow" must become invisible, a fully known and manageable production unit. However, these attempts to better accommodate the farm to the genomic market have not always been successful. In fact, it is here that the new commodity has become most contested: by being attached to a requalification of cattle and cattle owners as generators of "genomic life". For example, it seems that alternative cattle owner identities and ways of knowing and valuing cattle have become displaced - qualified as "othered" 
and illogical (Lorimer and Driessen 2013), as failing to participate in the shared project of improving the competitiveness of Finnish dairy production. In other words, the entangled attachments between genomic and other knowledge practices in breeding have not been fully recognized. Similarly, cattle that fail to conform to the ideals of the genomic era become devalued in the new market. This demonstrates that cattle owners and cattle are intricately connected in breeding: for example, the changing interpretation of the ideal cattle owner directly influences the lives (and deaths) of cattle. New attachments, co-produced at messier sites among more varied actors, might work towards stabilizing the market.

This paper has focused on the mechanisms of market creation and commodification. However, its findings underline the importance of critically examining the presence of biotechnologies in livestock production. Genomic breeding practices, like other biotechnological innovations, need to be judged on the impacts they have. The Finnish case shows that changes in breeding markets and practices can have broader repercussions on dairy production, extending beyond the seemingly closed-off world of livestock breeding by challenging what it means to be a cattle owner or a dairy cow in the genomic age. Further studies on the farm level are needed to explore the specific and localized impacts of the enhanced opportunities of commercial breeding. Specifically the ethical and moral questions of livestock breeding remain severely understudied, although breeding exerts extraordinary power over the lives of masses of animals, both individually and as populations. For example, genomic technologies could be harnessed to create solutions to the issues of sustainability and animal welfare, but they also have potential to contribute to the "thingification" (Buller 2013) and "machination" (Twine 2010; Rollin 2003) of animals, further establishing them as units of commodified life, as stock for companies to capitalize on. To conclude, this case has shown that more attention needs to be paid to the impact of changing breeding goals to human-animal relationships and the conditions of human and animal life thereof.

\section{ACKNOWLEDGEMENTS}

I wish to thank the University of Eastern Finland for funding this research, the Finnish Environment Institute for providing me with an inspiring working environment, and finally the two anonymous reviewers for their helpful comments. 


\section{REFERENCES}

Berndt, C. and M. Boeckler. 2009. Geographies of circulation and exchange: construction of markets. Progress in Human Geography 33(4): 535-551.

Bierma, J. 2015. After Bismark's fall. Holstein International 106: 20-21.

Birke, L. 1994. Feminism, animals and science: The naming of the shrew. Buckingham: Open University Press.

Boichard, D., V. Ducrocq, and S. Fritz. 2015. Sustainable dairy cattle selection in the genomic era. Journal of Animal Breeding and Genetics 132 (2): 135-43.

Buller, H. 2013. Individuation, the mass and farm animals. Theory, Culture \& Society 30 (7/8): $155-75$.

Callon, M., C. Méade, and V. Rabeharisoa. 2002. The economy of qualities. Economy and Society 31 (2): 194-217.

Callon, M. and F. Muniesa. 2005. Peripheral vision: Economic markets as calculative collective devices. Organization Studies 26 (8): 1229-50.

Castree, N. 2003. Commodifying what nature? Progress in Human Geography 27 (3): 273-97.

Collard, R-C. 2014. Putting animals back together, taking commodities apart. Annals of the Association of American Geographers 204 (1): 151-65.

Collard, R-C and J. Dempsey. 2013. Life for sale? the politics of lively commodities. Environment and Planning A, 45: 2682-99.

ICAR (International Committee for Animal Recording) 2014. Yearly enquiry on the situation of cow milk recording in ICAR member countries. Results for the years 20122013 [cited December/12 2016]. Available from http://www.icar.org/wp-content/ uploads/2015/08/Cow_Survey_Publication_2012-2013.pdf

Dant, T. 1999. Material culture in the social world: Values, activities, lifestyles. Buckingham: Open University Press.

Derry, M. 2015. Masterminding nature: The breeding of animals 1750-2010. Toronto: University of Toronto Press.

Eggen, A. 2012. The development and application of genomic selection as a new breeding paradigm. Animal Frontiers 2(1): 10-15.

European Commission - EU FADN. EU dairy farm report 2013 based on FDNA data. 2014 [cited February/25 2015]. Available from http://ec.europa.eu/agriculture/ rica/pdf/Dairy Farms report 2013 WEB.pdf 
FCCA. The FCCA's decision increases competition in the agriculture and forestry market. 2014 [cited October/31 2015]. Available from http://www.kkv.fi/en/current-issues/press-releases/2014/18.12.2014-the-fccas-decision-increases-competitionin-the-agriculture-and-forestry-market/.

Franklin, S. and M. Lock (eds.). 2003. Remaking life \& death: toward an anthropology of the biosciences. SAR press..

Gibbs, D., L. Holloway, B. Gilna, and C. Morris. 2009. Genetic techniques for livestock breeding: Restructuring institutional relationships in agriculture. Geoforum 40: 1041-9.

Goodman, D. and M. Redclift. 1991. Refashioning nature: Food, ecology and culture. London: Routledge.

Hayes, B. J., H. A. Lewin, and M. E. Goddard. 2013. The future of livestock breeding: Genomic selection for efficiency, reduced emissions intensity, and adaptation. Trends in Genetics 29 (4): 206-14.

Hannachi, M. and M. Tichit. 2016. Does biotechnological innovation require organizational innovation? Learning from the cattle breeding industry in France. Animal Frontiers 6 (1): 80-85.

Heller, C. and A. Escobar. 2003. Pure genes to GMOs: Transnationalized gene landscapes in the biodiversity and transgenic food networks. In Genetic Nature/Culture, eds. A. Goodman, S. Lindee, 155-175. Berkeley: University of California Press.

Holloway, L., C. Bear, and K. Wilkinson. 2014. Re-capturing bovine life: Robot-cow relationships, freedom and control in dairy farming. Journal of Rural Studies 33: 13140 .

Holloway, L. and C. Morris. 2008. Boosted bodies: Genetic techniques, domestic livestock bodies and complex representations of life. Geoforum 39 (5): 1709-20.

- 2012. Contesting genetic knowledge-practices in livestock breeding: Biopower, biosocial collectivities, and heterogeneous resistances. Environment and Planning $D$ $30: 60-77$.

- 2014. Viewing animal bodies: Truths, practical aesthetics and ethical considerability in UK livestock breeding. Social \& Cultural Geography 15 (1): 1-22.

Joyce, J., J. Nevins, and J. S. Schneiderman. 2015. Commodification, violence, and the making of workers and ducks at Hudson valley foie gras. In Critical animal geographies: Politics, intersection, and hierarchies in a multispecies world, eds. K. Gillespie, R-M Collard, 93-107. New York: Routledge.

Kloppenburg, J. 2005. First the seed: The political economy of plant biotechnology. Madison: University of Wisconsin Press.

Latour, B. 1993. We Have Never Been Modern. Harlow: Pearson. 
Lewontin, R. C. 1977. The relevance of molecular biology to plant and animal breeding. In Proceedings of the international conference on quantitative genetics., ed. E. Pollak, 55-65. Ames: lowa State University Press.

Lorimer, J., and C. Driessen. 2013. Bovine biopolitics and the promise of monsters in the rewilding of heck cattle. Geoforum 48 (8): 249-59.

Luke. Number of agricultural and horticultural enterprises by production sector and ELY Centre, 2015. [cited October/31 2015]. Available from http://stat.luke.fi/.

McAfee, K. 2003. Neoliberalism on the molecular scale. Economic and genetic reductionism in biotechnology battles. Geoforum 34 : 203-19.

Meyer, M. 2010. The rise of the knowledge broker. Science Communication 31 (1): $118-27$.

Mol, A. and J. Law. 2002. Complexities: Social studies of knowledge practices. Durham: Duke University Press.

Morris, C. and L. Holloway. 2009. Genetic technologies and the transformation of the geographies of UK livestock agriculture: A research agenda. Progress in Human Geography 33 (3): 313-33.

- 2014. Genetics and livestock breeding in the UK: Co-constructing technologies and heterogeneous biosocial collectivities. Journal of Rural Studies 33: 150-60.

MTK. Maidontuotanto Suomessa. 2015. [cited February/25 2015]. Available from https://www.mtk.fi/maatalous/maatilat_suomessa/maitotilat/fi_Fl/maitotilat/

Nimmo, R. 2011. Actor-network theory and methodology: social research in a more than human world. Methodological Innovations Online 6 (3): 108-119.

- 2004. Trading the genome: Investigating the commodification of bio-information. New York: Columbia University Press.

Parry, B. 2008. Entangled exchange: Reconceptualising the characterization and practice of bodily commodification. Geoforum 39: 1133-44.

Prudham, S. 2007. The fictions of autonomous invention: Accumulation by dispossession, commodification and life patents in Canada. Antipode 39 (3): 406-29.

Pryce, J. E. and H. D. Daetwyler. 2012. Designing dairy cattle breeding schemes under genomic selection: a review of international research. Animal Production Science 53(3): 107-114.

Ritvo, H. 1995. Possessing mother nature: genetic capital in eighteenth-century Britain. In Early modern conceptions of nature, eds. J. Brewer and S. Staves, 413-426. New York and London: Routledge.

Robertson, M. 2000. No net loss: Wetland restoration and the incomplete capitalization of nature. Antipode 32: 463-93. 
Rollin, B. 2003. Farm animal welfare. Oxford: Wiley.

Rossi, J. 2013. Socionatural engingeering of reductionist metaphors: a political ecology of synthetic biology. Environment and Planning A 45: 1127-1143.

Rossi, J. 2014. Genes are not information: Rendering plant genetic resources untradeable through genetic restoration practices. Geoforum 55: 66-75.

Sunder Rajan, K. 2006. Biocapital: The constitution of postgenomic life. Durham: Duke University Press.

Thacker, E. 2005. The global genome: Biotechnology, politics and culture. Cambridge: MIT Press.

Twine, R. 2010. Animals as biotechnology: Ethics, sustainability and critical animal studies. London: Earthscan.

Wainwright, J. and K. Mercer. 2011. Transnational transgenes: The political ecology of maize in Mexico. In Global political ecology, eds. R. Peet, P. Robbins and M. Watts, 412-430. New York: Routledge.

Whatmore, S. 1994. Global agro-food complexes and the refashioning of rural Europe. In Globalization, institutions and regional development in Europe, eds. A. Amin, N. Thrift, 46-67. Oxford: Oxford University Press.

Wynne, B. 2005. Reflexing complexity: Post-genomic knowledge and reductionist returns in public science. Theory, Culture \& Society 22 (5): 67-94. 